\title{
PEMBENTUKAN PERATURAN DAERAH MENGENAI PAJAK DAN RETRIBUSI DI KABUPATEN MALUKU TENGAH MENURUT PERSPEKTIF LEGISLASI RESPONSIF*
}

(The Formation of Local Regulation About Tax and Retribution District of Maluku Tengah Based on Responsive Legislation Perspective)

\author{
Dayanto dan Asma Karim \\ Fakultas Hukum Universitas Darussalam Ambon \\ JI. Raya Tulehu KM. 24 Ambon-Maluku \\ email: dayan_enlight@yahoo.co.id
}

Naskah diterima: 7 Oktober 2015; revisi: 27 November 2015; disetujui: 2 Desember 2015

\begin{abstract}
Abstrak
Adanya kebijakan desentralisasi yang berbasis pada otonomi yang luas maka urgensi untuk menghadirkan Peraturan Daerah yang berperspektif legislasi responsif menjadi kebutuhan, termasuk Peraturan Daerah mengenai Pajak dan Retribusi. Perspektif legislasi responsif bertolak dari indikator proses pembentukan yang partisipatif dan materi muatan yang aspiratif, sehingga permasalahan yang dikemukakan dalam penelitian ini adalah apakah proses pembentukan serta materi muatan Peraturan Daerah mengenai pajak dan retribusi di Kabupaten Maluku Tengah berperspektif legislasi responsif. Dengan tipe penelitian hukum normatif-empiris ini ditemukan bahwa Peraturan Daerah mengenai pajak dan retribusi di Kabupaten Maluku Tengah proses pembentukannya belum menunjukan adanya partisipasi masyarakat yang memadai dan materi muatannya belum mengakomodir aspirasi masyarakat, sehingga penelitian ini menyimpulkan bahwa pembentukan Peraturan Daerah mengenai Pajak dan Retribusi di Kabupaten Maluku Tengah belum berperspektif legislasi responsif. Agar praktik pembentukan Peraturan Daerah mengenai Pajak dan Retribusi di Kabupaten Maluku Tengah dapat berkesesuaian dengan tujuan otonomi daerah maka pembentukannya harus didasarkan pada perspektif legislasi responsif. Kata Kunci: peraturan daerah responsif, pajak, retribusi
\end{abstract}

\section{Abstract}

The policy of decentralization based on autonomy brings the necessity and urgency to make the Local Regulation with responsive legislation perspective, including the Local Regulation on Tax and Retribution. Responsive legislation perspective based itself on some indicators like a participative process on forming the regulation and an aspirative subject matters. Therefore the issues raised in this research is whether the formation process and subject matters of Regional Regulations on Tax and Retribution in district of Maluku Tengah has already had a responsive legislation perspective. This normativeempirical legal research found that the Local Regulation on Tax and Retribution in district of Maluku Tengah has not shown enough public participation in its formation process and has not accommodate public aspirations in its subject matters, so this research concluded that the formation of Local Regulations on Tax and Retribution in district of Maluku Tengah has not had a responsive legislation perspective. To make the formation of Local Regulations about Tax and Retribution in district of Maluku Tengah compatible with the objective of local autonomy, the formation should be based on the responsive legislation perspective.

Keywords: responsive local regulation, tax, retribution

Artikel ini merupakan sebagian Hasil Penelitian/Riset yang dilaksanakan atas biaya DIPA Direktorat Penelitian dan Pengabdian Masyarakat DIKTI Nomor DIPA-023.04.1.673453/2015, Tanggal 14 November 2014. Peneliti mengucapkan terima kasih 3 (Tiga) mahasiswa: M. Alim Tomu, Syuaib Hermanses, dan Swanda Angkotasan atas partisipasinya dalam Penelitian ini. 


\section{A. Pendahuluan}

Keberadaan Peraturan Daerah (Perda) mengenai Pajak dan Retribusi merupakan konsekwensi logis dari diterapkannya kebijakan desentralisasi yang berbasis pada otonomi yang luas sebagaimana yang awalnya diatur dalam Undang-Undang Nomor 22 Tahun 1999 maupun penggantinya Undang-Undang Nomor 32 Tahun 2004 yang telah diganti pula dengan Undang-Undang Nomor 23 Tahun 2014 tentang Pemerintahan Daerah. Kebijakan desentralisasi ini memberikan kewenangan yang luas kepada daerah termasuk dalam hal meningkatkan Pendapatan Asli Daerah melalui Pajak Daerah dan Retribusi Daerah sesuai dengan UndangUndang Nomor 28 Tahun 2009 tentang Pajak Daerah dan Retribusi Daerah.

Otonomi daerah merupakan esensi pemerintahan desentralisasi yang mencakup makna membuat perundang-undangan sendiri (zelfwetgeving) serta pemerintahan sendiri (zelfbestuur). Dimana Zelfwetgeving mencakup membuat Perda sebagai dasar untuk mengatur rumah tangga sendiri (eigen huishouding). ${ }^{1}$ Dalam pemerintahan desentralisasi yang berbasis pada otonomi yang luas itulah, tuntutan untuk menghadirkan produk Perda yang responsif menjadi kebutuhan yang tidak terelakkan. Sebab, agar kinerja penyelenggaraan otonomi daerah dapat berlangsung secara baik maka diperlukan kapasitas responsif yang dua arah atau timbal balik dari unsur pemerintahan daerah dengan masyarakatnya.
Kapasitas responsif dari unsur pemerintahan daerah ditandai dengan adanya DPRD dan Kepala Daerah yang akomodatif terhadap setiap aspirasi logis dari masyarakat dalam keseluruhan proses pengambilan kebijakan daerah, sedangkan kapasitas responsif dari masyarakat ditandai dengan kemampuannya untuk terlibat dalam melakukan pengawasan ataupun memberikan input secara partisipatif dalam keseluruhan proses pengambilan kebijakan tersebut, termasuk dalam hal kebijakan membuat peraturan perundangundangan sendiri (zelfwetgeving).

Akan tetapi, dalam mengaktualisasikan makna membuat perundang-undangan sendiri (zelfwetgeving) itu justru dijumpai begitu banyak Perda yang telah diundangkan oleh pemerintah provinsi maupun kabupaten/kota dalam kategori bermasalah. Diungkapkan oleh Kementerian Hukum dan Hak Asasi Manusia dalam Harian Kompas Tanggal 25 Juli 2011 bahwa sejauh ini sekitar 4.000 Perda di Indonesia. Akibat pembatalan tersebut, dana senilai Rp. 1,2 Triliun yang dipakai untuk membuat Perda itupun hilang.

Berdasarkan Keputusan Menteri Dalam Negeri tentang Pembatalan Perda dan Keputusan Kepala Daerah Tahun 2005-2009, untuk beberapa Kabupaten/Kota di Provinsi Maluku pada sepanjang tahun 2002 sampai 2009 jumlah Perda yang dibatalkan oleh Kementerian Dalam Negeri, antara lain: Kota Ambon sebanyak 8 Perda, Kabupaten Maluku Tenggara sebanyak 2 Perda, Kabupaten Maluku 
Tenggara Barat sebanyak 24 Perda, Seram Bagian Barat sebanyak 20 Perda, termasuk Kabupaten Maluku Tengah sebanyak 21 Perda.

Secara nasional, Perda yang dibatalkan berdasarkan jenis pajak daerah, retribusi daerah dan Perda lainnya dapat dilihat pada tabel di bawah ini: bahwa salah satu kriteria sebuah Perda dikategorikan sebagai Perda Bermasalah yakni Perda tersebut dibuat dan dilaksanakan tidak memperhatikan prinsip-prinsip dasar ekonomi/ investasi dengan kata lain meningkatkan pajak secara berlebihan sehingga mengakibatkan timbulnya hight cost economy. ${ }^{4}$

Tabel 1. Daftar Perda Berdasarkan Jenis Pajak, Retribusi, dan Lain-Lain

\begin{tabular}{ccccc}
\hline Tahun & Pajak & Retribusi & Lain-Lain & Jumlah \\
\hline 2005 & 17 & 74 & 29 & 120 \\
\hline 2006 & 9 & 97 & 3 & 109 \\
\hline 2007 & 9 & 123 & 38 & 170 \\
\hline 2008 & 40 & 151 & 37 & 228 \\
\hline 2009 & 134 & 445 & 253 & 832 \\
\hline $2009 *$ & 83 & 233 & 90 & 406 \\
\hline JUMLAH & 292 & 1.123 & 450 & 1.865 \\
\hline
\end{tabular}

Sumber : Biro Hukum Kemendagri, Tahun 2010 (Hattu, 2010)

NB : 2009*: Pembatalan sesuai Program 100 Hari Kabinet Indonesia Bersatu II

Data pada Tabel di atas mendeskripsikan bahwa dari total 1.865 Perda yang diproduk sejak tahun 2005 sampai dengan tahun 2009 terdapat 292 Perda mengenai Pajak dan 1.123 Perda mengenai Retribusi yang dibatalkan. Dampak serius yang ditimbulkan dari banyaknya Perda tentang Pajak dan Retribusi daerah, adalah melambatnya arus investasi di daerah, karena para investor menganggap pajak-pajak dan retribusi-retribusi tersebut sangat membebani mereka. ${ }^{3} \mathrm{Hal}$ ini sejalan dengan pandangan
Selain itu, Perda Bermasalah juga meliputi Perda-Perda yang tidak dirancang atau disusun sesuai dengan prinsip-prinsip pembuatan peraturan perundang-undangan (legislative drafting) yang sedang berlaku serta Perda-Perda itu hanya dibuat oleh pihak eksekutif daerah atau legislatif daerah tanpa melibatkan cukup partisipasi rakyat (stake holders) yang pada dasarnya mengerti kondisi apa yang mereka aspirasikan dan sesuai dengan kondisi daerah. ${ }^{5}$

2 Hendrik Hattu, Model Undang-Undang Berkarakter Responsif (Studi Atas Undang-Undang Nomor 32 Tahun 2004 tentang Pemerintahan Daerah), Ringkasan Disertasi (Makassar: Program Pasca Sarjana Universitas Hasanuddin, 2010), hlm. 78.

3 Bandingkan dengan H. M. Jusup, “Perda Pajak Dan Retribusi Daerah Di Era Otonomi Daerah”, Jurnal Ekonomi, Vol. 1 No. 1 (September-Desember 2012): 102.

4 Lihat Isrok, "Korelasi Antara Peraturan Daerah (Perda) bermasalah dengan Tingkat Investasi Ke Daerah", Jurnal Hukum, Vol. 16 No. 4 (Oktober 2009): 566.

5 Ibid 
Tidak bisa dipungkiri bahwa untuk menyelenggarakan pemerintahan Daerah, suatu Daerah Otonom berhak mengenakan pungutan kepada masyarakat dalam bentuk Pajak dan Retribusi sebagaimana diatur dalam UndangUndang Nomor 28 Tahun 2009 tentang Pajak Daerah dan Retribusi Daerah melalui suatu Perda. Sehingga wajar bila peningkatan Pendapatan Asli Daerah dijadikan salah satu indikator kesiapan daerah dalam menjalankan kebijakan otonomi ${ }^{6}$, termasuk dalam hal kewenangan pengelolaan keuangan dalam bentuk diterbitkannya Perda mengenai Pajak dan Retribusi. Namun, yang harus diperhatikan ialah pengenaan Pajak dan Retribusi hendaknya seiring dengan tingkat pendapatan masyarakat serta pelayanan yang diberikan oleh pemerintah daerah. ${ }^{7}$ Dengan demikian, dalam pembentukan Perda mengenai Pajak dan Retribusi tersebut haruslah tetap mencerminkan adanya partisipasi dan akomodasi aspirasi para wajib Pajak dan Retribusi serta stakeholder lainnya agar materi Perda tersebut dapat efektif berlaku.

Berdasarkan uraian di atas maka penelitian ini akan membahas apakah proses pembentukan Perda mengenai Pajak dan Retribusi di Kabupaten Maluku Tengah berperspektif legislasi responsif, serta apakah materi muatan Perda Mengenai Pajak dan Retribusi di Kabupaten Maluku Tengah berperspektif legislasi responsif.

\section{B. Metode Penelitian}

Penelitian yang berlokasi di Kabupaten Maluku Tengah ini mengacu pada tipe penelitian hukum normatif-empiris yakni penelitian tentang penerapan hukum in abstracto dalam kenyataan (in concrito) di masyarakat. Hukum in abstracto dimaksud adalah konsep tentang indikator legislasi reponsif serta norma yang terkandung dalam Ketentuan tentang partisipasi masyarakat dalam Undang-Undang Nomor 12 Tahun 2012 tentang Pembentukan Peraturan Perundang-undangan.

Data primer dalam penelitian ini dikumpulkan melalui wawancara mendalam (indepth interview) dengan informan wajib pajak dan wajib retribusi serta Pimpinan Badan Pembentukan Perda dan Pimpinan Bagian Hukum Kabupaten Maluku Tengah yang dipilih secara purposive. Adapun data sekunder antara lain: Undang-Undang Nomor 12 Tahun 2011 tentang Pembentukan Peraturan PerundangUndangan, Undang-Undang Nomor 28 Tahun 2009 tentang Pajak Daerah dan Retribusi Daerah, Produk-Produk Perda Kabupaten Maluku Tengah mengenai Pajak dan Retribusi, dan Peraturan Tata Tertib DPRD Kabupaten Maluku Tengah, yang dikumpulkan melalui penelusuran dokumen. Selain itu digunakan studi kepustakaan (library research) terhadap kajian-kajian hukum dan non hukum yang berkaitan dengan permasalahan penelitian. Data yang terkumpul dianalisis secara deskriptif kualitatif.

Lihat Adian Sutedi, Hukum Pajak dan Retribusi Daerah (Bogor: Ghalia Indonesia, 2008), hlm.5. Ibid. 


\section{Pembahasan}

\section{Proses Pembentukan Peraturan Daerah Tentang Pajak Di Maluku Tengah}

Menurut Nonet dan Selznick ${ }^{8}$, tipe hukum yang responsif itu adalah hukum yang siap mengadopsi paradigma baru dan meninggalkan paradigma lama. Dengan demikian, di dalam hukum yang responsif terbuka lebar ruang dialog dan wacana serta adanya pluralistik gagasan sebagai sebuah realitas.

Dikemukakan oleh F.X. Adji Samekto, Ide dasar hukum responsif yang dikemukakan oleh Nonet dan Selznick adalah menafsirkan dan mereformulasi ketentuan-ketentuan hukum sesuai dengan fakta (to interpret and reformulated rules in light of their actual consequences). Nonet dan Selznick selanjutnya juga menyatakan: in the ideal of responsive law, law is fasBerangkan dari ilitator of response of social needs and aspiration. ${ }^{9}$

Berangkat dari pandangan Nonet dan Selznick, Mukhtie Fadjar ${ }^{10}$ mengemukakan bahwa tipe Hukum Responsif, berdasar pada sifat responsif yang dapat diartikan sebagai melayani kebutuhan dan kepentingan sosial yang dialami dan ditemukan tidak oleh pejabat melainkan oleh rakyat. Tipe Hukum Responsif tidak membuang ide tentang keadilan formal, tetapi memperluasnya agar mencakup keadilan substantif, dua ciri yang menonjol dari Tipe Hukum Responsif, yakni:

a) Pergeseran penekanan dari aturan-aturan ke prinsip-prinsip dan tujuan; dan

b) Pentingnya watak kerakyatan (populis) baik sebagai tujuan hukum maupun cara untuk mencapainya."

Dalam tipe hukum responsif, pluralisme hukum diakui, tidak disetujuinya kecenderungan para positivis untuk mengubah setiap bentuk penataan sosial menjadi suatu pelaksanaan otoritas negara. Salah satu dampak pluralisme hukum adalah memperluas kesempatan dalam proses hukum untuk berpartisipasi dalam pembuatan hukum. Dengan cara ini, arena hukum menjadi sebuah bentuk forum politik tertentu. dan partisipasi hukum melibatkan dimensi politik. Dengan kata lain, tindakan hukum menjadi kenderaan bagi sekelompok orang atau organisasi untuk berpartisipasi dalam menetapkan kebijakan publik. ${ }^{12}$

Berdasarkan konsepsi tipe hukum responsif tersebut maka dikonseptualisasi indikator karakter hukum responsif yang mana hal ini

8 Rodiyah, "Aspek Demokrasi Pembentukan Peraturan Daerah Dalam Perspektif Socio-Legal",Jurnal MMH, Jilid 41 No. 1(2012):149-150. Nonet dan Selznick, dalam bukunya berjudul Law and Society in Transition, Toward Responsive Law mengemukakan bahwa ada hubungan yang signifikan antara sistem pemerintahan sebuah negara dengan hukum yang dianutnya. Dalam sistem pemerintahan yang otoriter, hukum menjadi subordinasi dari politik. Artinya, hukum mengikuti politik. Dengan kata lain, hukum digunakan hanya sekadar menunjang politik penguasa. Sebaliknya dalam sistem pemerintahan yang demokratis, hukum terpisah secara diametral dari politik. Artinya, hukum bukan menjadi bagian dari politik, akan tetapi hukum menjadi acuan berpolitik dari sebuah bangsa. Lihat Henry Arianto, "Hukum Responsif dan Penegakkan Hukum Di Indonesia", Jurnal Lex Jurnalica, Vol. 7 No.2 (April 2010): 116.

9 Lihat F.X. Adji Samekto, "Relasi Hukum dengan Kekuasaan: Melihat Hukum Dalam Perspektif Realitas", Jurnal Dinamika Hukum, Vol. 13 No. 1 (Januari 2013): 94.

10. Mukhtie Fadjar, Teori-Teori Hukum Kontemporer (Malang: Setara Press, 2013), hlm, 55.

11 Ibid.

12 Philippe Nonet dan Philip Selznick, Hukum Responsif, Penerjemah (Raisul Muttaqien), Cetakan Kedua (Bandung: Nusa Media, 2008), hlm. 107-108. 
berhubungan dengan konfigurasi politik dan sistem hukum pemerintahan suatu negara. Moh. Mahfud MD mengatakan bahwa politik seringkali mengintervensi pembuatan dan pelaksanaan hukum, sehingga tidak selalu menjamin kepastian hukum, penegakkan hak-hak masyarakat atau penjamin keadilan. Konfigurasi politik demokratis akan menciptakan hukum responsif, sedangkan konfigurasi politik otoriter akan menciptakan produk hukum konservatif. ${ }^{13}$

Lebih lanjut Moh. Mahfud MD ${ }^{14}$ memberikan eksplanasi bahwa produk hukum yang berkarakter responsif proses pembuatannya bersifat partisipatif, yakni mengundang sebanyak-banyaknya partisipasi masyarakat serta dilihat dari fungsinya maka hukum yang berkarakter responsif bersifat aspiratif. Artinya memuat materi-materi yang secara umum sesuai dengan aspirasi atau kehendak masyarakat yang dilayaninya.

Dengan demikian produk legislasi responsif dalam penelitian ini didasarkan pada indikator: proses pembuatan atau pembentukannya yang partisipatif dan materi muatannya bersifat aspiratif. Indikator responsif ini sejalan dengan urgensi partisipasi masyarakat dalam pembentukan peraturan perundang-undangan diatur dalam Pasal 96 ayat (1) Undang-Undang
Nomor 12 Tahun 2011, yang menegaskan bahwa masyarakat berhak memberikan masukan secara lisan dan/atau tertulis dalam Pembentukan Peraturan Perundang-undangan.

Secara konsepsional, partisipasi merupakan suatu konsep yang merujuk pada keikutsertaan seseorang dalam berbagai aktivitas pembangunan. ${ }^{15}$ Partisipasi masyarakat dalam proses pembentukan Perda dapat dikategorikan sebagai partisipasi politik, yang menurut Huntington dan Nelson partisipasi politik adalah kegiatan warga negara sipil (privat citizen) yang bertujuan mempengaruhi pengambilan keputusan oleh pemerintah. ${ }^{16}$

Mengenai partisipasi masyarakat dalam pembentukan Perda, Jazim Hamidi, dkk, mendefenisikan partisipasi sebagai peran serta atau keikutsertaan (mengawasi, mengontrol, dan mempengaruhi) masyarakat dalam suatu kegiatan pembentukan Perda mulai dari perencanaan sampai dengan evaluasi pelaksanaan Perda. ${ }^{17}$

\section{a. Analisis Partisipasi Masyarakat pada Tahap Perencanaan Peraturan Daerah}

Berdasarkan indikator legislasi responsif di atas, maka proses pembentukan Perda yang memenuhi karakter responsif ditandai dengan proses pembentukannya yang partisipatif.

3 Lihat Iza Rumesten R.S, "Model Ideal Partisipasi Masyarakat Dalam Pembentukan Peraturan Daerah", artikel dalam Jurnal Dinamika Hukum,Vol. 12 No. 1 (Januari 2012): 136. Lihat pula Hendrik Hattu, "Tahapan UndangUndang Responsif", Jurnal Mimbar Hukum, Vol. 23 No.2 (2011): 410.

14 Moh. Mahfud MD, Politik Hukum Di Indonesia (Jakarta: PT Raja Grafindo Persada, 2009), hlm. 31-32.

15 Iza Rumesten R.S, "Strategi Hukum dan Penerapan Partisipasi Masyarakat dalam Penyelesaian Sengketa Batas Daerah di Sumatera Selatan", Jurnal Hukum Ius Quia Iustum, Vol. 20 No. 4 (Oktober 2013):618. Bandingkan dengan Tomy M Saragih, "Konsep Partisipasi Masyarakat Dalam Pembentukan Peraturan Daerah Rencana Detail Tata Ruang dan Kawasan”, JurnalSasi, Vol. 17 No. 3 (2011):11.

16 Muhammad Syaifuddin, et.al, "Demokratisasi Peraturan Daerah: Pengembangan Model Ideal Pembentukan Peraturan Daerah Demokratis di Bidang Ekonomi di Kabupaten/Kota di Provinsi Sumatera Selatan”, artikel dalam JurnalMMH, Jilid 39, No. 2 (2010):113.

17 Jazim Hamidi, et.al, Panduan Praktis Pembentukan Peraturan Daerah Partisipatif (Jakarta: Prestasi Pustaka Publisher, 2008), hlm. 48. 
Berdasarkan Pasal 1 angka 1 Undang-Undang Nomor 12 Tahun 2011 tentang Pembentukan Peraturan Perundang-Undangan dirumuskan bahwa Pembentukan Peraturan Perundangundangan adalah pembuatan Peraturan Perundang-undangan yang mencakup tahapan perencanaan, penyusunan, pembahasan, pengesahan atau penetapan, dan pengundangan.

Praktik partisipasi masyarakat dalam perencanaan pembentukan Perda dapat dicermati dalam proses penyusunan program legislasi daerah sebagai awal Pembentukan Perda. Ketentuan Pasal 1 angka 10 UndangUndang Nomor 12 Tahun 2011 Tentang Pembentukan Peraturan Perundang-Undangan menyatakan bahwa: "Program Legislasi Daerah yang selanjutnya disebut Prolegda adalah instrumen perencanaan program pembentukan Peraturan Daerah Provinsi atau Peraturan Daerah Kabupaten/Kota yang disusun secara terencana, terpadu, dan sistematis". ${ }^{18}$

Dalam praktiknya, proses perencanaan tentang Perda mengenai Pajak yang dituangkan dalamprogram legislasi daerah sama sekali tidak melibatkan partisipasi masyarakat sebagaimana diungkapkan oleh responden wajib Pajak dan Retribusi bahwabelum pernah terlibat dalam proses perencanaan/program legislasi daerah khusunya yang berkaitan dengan rencana pembentukan Perda mengenai Pajak dan Retribusi ${ }^{19}$, hal ini senada dengan yang diakui oleh Kepala Bagian Hukum Sekretariat Daerah Kabupaten Maluku Tengah bahwa proses perencanaan/program legislasi daerah selama inimasih merupakan pembicaraan dan kesepakatan dua pihak antara DPRD dan Pemerintah Daerah dimana partisipasi masyarakat belum dilibatkan dalam proses $\mathrm{ini}^{20}$.

Hal ini menunjukan bahwa sejak awal yakni pada tahap perencanaan pembentukan Perda mengenai Pajak dan Retribusidi Kabupaten Maluku Tengah masihtidak menunjukan berkarakter yang responsifdimana peranan lembaga-lembaga negara (dalam hal ini DPRD dan pemerintah daerah) sangat dominan dalam menentukan rencana dan arah pembentukan Perda mengenai Pajak dan Retribusi.

\section{b. Analisis Partisipasi Masyarakat dalam Penelitian atau Pengkajian}

Dalam kaitannya denganpenyusunan rancangan Perda perlu dilakukan penelitian atau pengkajian ${ }^{21}$ yang nantinya berujung pada

18 Dalam proses penyusunan program legislasi daerah ini Badan Pembentuk Peraturan Daerah DPRD dan Bagian Hukum Pemerintah Daerah memegang peranan penting, terutama dalam mengkoordinasi penyusunan program legislasi daerah antara DPRD dan Pemerintah Daerah. Di tahapan perencanaan ini baik pemerintah daerah maupun DPRD sama-sama mengusulkan rencana Peraturan Daerah yang nantinya akan dibahas secara terencana, terpadu dan sistematis.

19 Hasil wawancara mendalam dengan Risal (Wajib Pajak Hotel), 17 April 2015 dan Ratih Sumantri (Wajib Pajak Restoran), 19 April 2015, serta Anyong Paiman(Wajib Retribusi Pelayanan Pasar), 18 April 2015.

20 Hal ini sangat berbeda dengan rencana legislasi daerah yang berkaitan dengan isu dan kebutuhan pemekaran Desa atau Negeri yang cenderung muncul sebagai respon terhadap aspirasi yang berkembang di masyarakat yang membutuhkan pemekaran tersebut, sehingga partisipasi masyarakat dalam perumusan program legislasi daerah mengenai pemekaran Desa atau Negeri tersebut sudah dapat dirasakan. Hasil wawancara mendalam dengan Z. atekay, S.H. (Kepala Bagian Hukum Sekretariat Daerah Kabupaten Maluku Tengah), 21 April 2015.

21 Tahap penelitian atau pengkajian merupakan tahap awal dalam penyusunan rancangan Peraturan Daerah. 
laporan penelitian berupa naskah akademik ${ }^{22}$ yang menjadi acuan dalam penyusunan materi muatan suatu produk hukum. Isyarat perlunya penelitian atau pengkajian tersebut ditegaskan dalam Undang-Undang Nomor 12 Tahun 2011 sebagaimana yang ditekankan dalam Ketentuan Pasal 1 angka 11 mengenai naskah akademik sebagai laporan hasil penelitian atau pengkajian.

Konsepsi yang dikonstruk oleh ketentuan yang mengandaikan adanya urgensi penelitian dan pengkajian yang nantinya berujung pada rumusan naskah akademik sebagaimana yang dimuat dalam Undang-undang Nomor 12 Tahun 2012 itu linier dengan dalam teori perancangan peraturan perundang-undangan yang disebut sebagai The Three Pilars of quality of Legal Product, jika divisualisasi seperti gambar di di bawah ini:. ${ }^{23}$

Gambar 1. Teori Perancangan Pembentukan Peraturan Perundang-Undangan: The Three Pillars of Quality of Legal Productoleh Achmad Ruslan

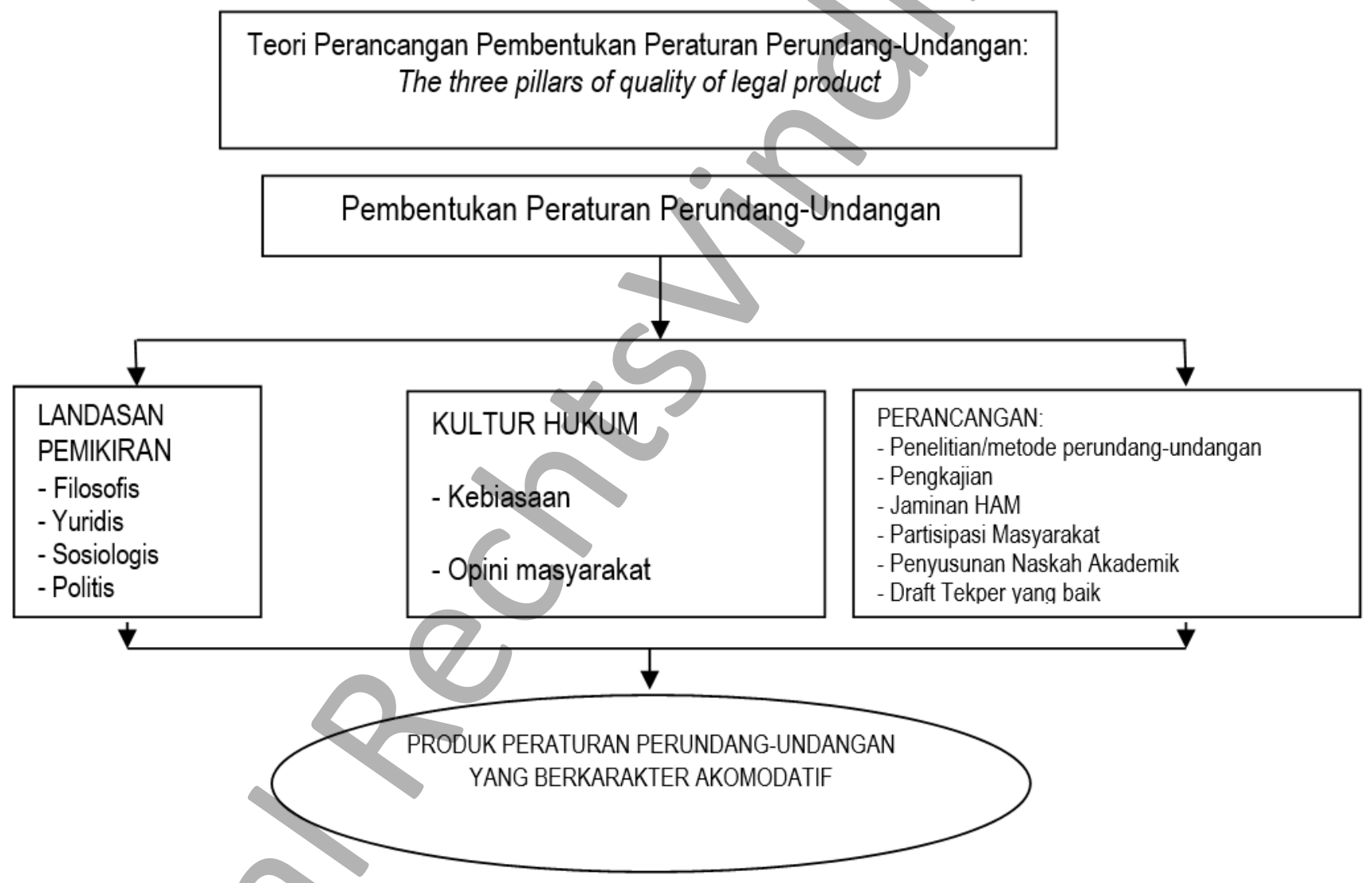

22 Naskah akademik merupakan media nyata bagi peran serta masyarakat dalam proses pembentukan atau penyusunan peraturan perundang-undangan bahkan inisiatif penyusunan atau pembentukan naskah akademik dapat berasal dari masyarakat. Harry Alexander dalam Abdul Basyir, "Pentingnya Naskah Akademik Dalam Pembentukan Peraturan Perundang-undangan Untuk Mewujudkan Hukum Aspiratif Dan Responsif”, Jurnal Ius, Vol. II No.5 (Agustus 2014):291.

23 Achmad Ruslan, Teori dan Panduan Pembentukan Peraturan Perundang-Undangan Di Indonesia (Yogyakarta: Mahakarya Rangkang Offset, 2011), hlm. 145. 
Perda mengenai Pajak dan Retribusi secara umum memiliki fungsi: ${ }^{24}$ Pertama,perda pajak dan retribusi adalah fungsi anggaran yang erat kaitannya dengan fungsi perencanaan. Kedua,perda pajak dan retribusi sehubungan dengan anggaran adalah fungsi pengaturan. Ketiga, perda pajak dan retribusi sebagai instrumen anggaran adalah fungsi distribusi. Berkaitan dengan fungsi-fungsi tersebut maka, pembentukan Perda mengenai Pajak dan Retribusi diperlukan suatu pengkajian dan penelitian yang mendalam, sehingga Perda tersebut dapat memiliki kekuatan filosofis, kekuatan sosiologis, kekuatan yuridis secara sekaligus yang pada gilirannya tidak berakhir sebagai Perda yang dikategorikan bermasalah.

Berdasarkan penelusuran peneliti bahwa dalam praktiknya penyusunan rancangan Perda tidak ada satupun Rancangan Perda mengenai Pajak dan Retribusi di Kabupaten Maluku Tengahyang disertai dengan naskah akademik. Rancangan Perda yang diajukan untuk dibahas tersebut hanya disertai dengan keterangan. Ini menjelaskan bahwa dalam proses perancangan Perda mengenai Pajak dan Retribusitidak melalui suatu kegiatan penelitian atau pengkajian.

Padahal, sebagaimana yang dikemukakanRia Casmi Arrsa, praktik politik legislasi dalam proses pembentukan Rancangan Perda berbasis riset merupakan suatu kemutlakan untuk melahirkan Perda yang berkualitas dan memiliki dasar keabsahan baiksecara yuridis maupun akademis. Pelembagaan naskah akademik ke depan tidak semata-mata ditempatkan pada kerangka prosedural formal sebagai dokumen pelengkap semata dalam proses pembahasan di DPRD (baik pada tingkat Provinsi, Kabupaten/Kota), akan tetapi merupakan suatu dokumen yang memiliki kesinambungan dan kesatuan prinsip dasar kajian dalam pembentukan Rancangan Perda yang dapat dipertanggungjawabkan secara akademik. ${ }^{25}$

Dengan demikian, pada tahapan ini tidak terdapat partisipasi masyarakat. Padahal partisipasi masyarakat dalam bentuk penelitian atau pengkajian dalam rangka perancangan Perda mengenai Pajak dan Retribusi dapat dilakukan baik oleh instansi Pemerintah atau kerjasama antara instansi pemerintah dengan masyarakat atau dilakukan secara mandiri oleh masyarakatterutama oleh kalangan Perguruan Tinggi atau Lembaga Swadaya Masyarakat dengan melibatkan para ahli atau pakar yang kompeten sesuai dengan substansi Perda yang akan dirancang.

\section{c. Analisis Partisipasi Masyarakat dalam Penyusunan Naskah Rancangan Perda}

Pada tahap penyusunan naskah Rancangan Perda urgensi partisipasi masyarakat secara eksplisit disebutkan dalam Undang-Undang Nomor 12 Tahun 2011 tentang Pembentukan Peraturan Perundang-Undangan, Pasal 92 ayat (1) dan (2) menyebutkan:

1) Pasal 92 ayat (1): Penyebarluasan Prolegda dilakukan oleh DPRD dan Pemerintah Daerah sejak penyusunan Prolegda, penyusunan Rancangan Peraturan Daerah, pembahasan

Himawan Estu Bagijo, "Pajak Dan Retribusi Daerah Sebagai Sumber Pendapatan Daerah (Studi Kasus Di Kabupaten/Kota Dan Pemerintah Propinsi Di Jawa Timur)", Jurnal Perspektif, Vol. XVI No. 1 (2011): 13.

25 Ria Casmi Arrsa, “Restorasi Politik Legislasi Pembentukan Peraturan Daerah Berbasis Riset”, JurnalRechtsvinding, Vol. 2 No. 3, (Desember 2013): 413-414. 
Rancangan Peraturan Daerah, hingga

Pengundangan Peraturan Daerah.

2) Pasal 92 ayat (2) : Penyebarluasan sebagaimana dimaksud pada ayat (1) dilakukan untuk dapatmemberikan informasi dan/atau memperoleh masukan masyarakat dan para pemangku kepentingan.

Ketentuan tersebut kemudian dipertegas lagi pada Pasal 96 ayat (1) dan (2) yang menyebutkan :

1. Masyarakat berhak memberikan masukan secara lisan dan/atau tertulis dalam pembentukan peraturan perundanganundangan.

2. Masukan secara lisan dan/atau tertulis sebagaimana dimaksud pada ayat (1) dapat dilakukan melalui (a) rapat dengan pendapat umum, (b) kunjungan kerja, (c)sosialisasi dan/atau (d) seminar, lokakarya dan/atau diskusi.

Hasil penelitian menunjukan, pada tahap penyusunan naskah Rancangan Perda mengenai Pajak Kabupaten Maluku Tengah, pelibatan partisipasi masyarakat umumnya mulai terlihat bahwa masyarakat yang terkena dampak kebijakan Perda dilibatkan dalam forum dengar pendapat untuk memberi masukan dan mengkritisi Rancangan Perda mengenai Pajak dan Retribusi, dimana salah satu isu yang mendapatkan perhatian khusus pada forum tersebut adalah mengenai besar nilai tarif Pajak. ${ }^{26}$

Mengenai tahap penyusunan naskah Rancangan Perda mengenai Pajak Daerah diungkapkan oleh Ketua Asosiasi Pengusaha Hotel Maluku Tengah bahwa:
Selama ini kita baru pernah dipanggil satu kali untuk dengar pendapat oleh Komisi yang membidangi persoalan Pajak dan Retribusi ini sekitar 2 (dua) Tahun lalu. Itupun hanya beberapa pengusaha yang hadir walaupun yang diundang sangat banyak. Pada saat itu, sebagai pengusaha Hotel kami memberikan masukan agar nilai Pajak 10 $\%$ dapat dipertimbangkan agar seimbang dengan kemampuan ekonomi pengunjung dan kondisi ekonomi daerah saat ini. Namun ternyata, yang diputuskan adalah besar nilai Pajak $10 \%$ dengan alasan untuk membiayai pembangunan daerah

Walaupun pelibatan masyarakat sudah terlihat dalam tahap penyusunan naskah Raperda mengenai Pajak dan Retribusi, namun dari aspek kuantitatif masih minim dan dari aspek pelaku partisipasi masih sangat terbatas. Hal ini tentu menyebabkan artikulasi aspirasi dari masyarakat dalam proses penyusunan naskah Raperda mengenai Pajak dan Retribusi Daerah itu menjadi sangat tidak memadai. Padahal partisipasi yang merupakan hak masyarakat sebagai warga negara tersebut merupakan kebutuhan yang wajib dipenuhi oleh negara dalam hal ini DPRD dan pemerintah daerah.

\section{d. Analisis Partisipasi Masyarakat pada Tahap Pembahasan}

Pada ketentuan Pasal 92 ayat (1) UndangUndang Nomor 12 Tahun 2011 tentang Pembentukan Peraturan PerundangUndangan menjadi landasan normatif bagi urgensipartisipasi masyarakat sejak perencanaan, pembahasan, penetapan, pengesahan, hingga Pengundangan Perda. Mekanisme tersebut kemudian disesuaikan 
dengan Tata Tertib DPRD dengan akses partisipasi memungkinkan masyarakat untuk menyampaikan aspirasi atau menyumbangkan pemikirannya terhadap suatu kebijakan yang akan diambil oleh Pemeritah Daerah.

Dalam Pasal 150 ayat (1) Peraturan Dewan Perwakilan Rakyat Daerah Kabupaten Maluku Tengah Nomor 01 Tahun 2009 tentang Tata Tertib Dewan Perwakilan Rakyat Daerah Kabupaten Maluku Tengah, dirumuskan bahwa: "Pembahasan Raperda dilakukan oleh Dewan Perwakilan Rakyat Daerah bersama melibatkan masyarakat. ${ }^{28} \mathrm{Hal}$ ini menunjukan proses pembentukan Perda di Kabupaten Maluku Tengah, termasuk Perda tentang Pajak dan Retribusi bersifat sangat elitis yakni tanpa sedikitpun melibatkan partisipasi masyarakat.

Padahal, sesungguhnya partisipasi masyarakat dalam tahap pembahasan merupakan tahapan yang sangat penting, mengingat pada tahap inilah suatu rancangan Perda akan memasuki ranah kepentingan politik yang dilakukan oleh DPRD sebagai pemegang kekuasaan fungsi legislasi daerah.

Gambar 2. Tahapan Perkembangan Naskah Rancangan Peraturan Daerah

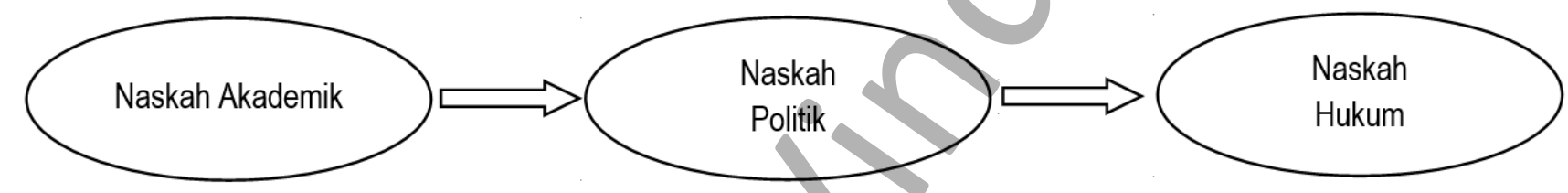

Bupati".Peraturan ini kemudian diganti dengan Peraturan Dewan Perwakilan Rakyat Daerah Nomor 01 Tahun 2014 tentang Tata Tertib Dewan Perwakilan Rakyat, yang mana pengaturan tentang pembahasan Perda terdapat dalam Pasal 90 ayat (1) bahwa "Rancangan peraturan yang berasal dari DPRD atau Bupati dibahas oleh DPRD dan Bupati untuk mendapatkan persetujuan bersama".

Hasil yang ditemukan oleh peneliti bahwa pada tahapan pembahasan ini pihak DPRD Kabupaten Maluku Tengah berpandangan bahwa peraturan tata tertib hanya mengikat internal DPRD, dimana tahap pembahasan Raperda merupakan pembicaraan antara DPRD dan Bupati sehingga tidak ada kewajiban untuk
Dalam tahap pembahasan ini, Raperda terlebih yang menggunakan naskah akademik akan diuji oleh kekuatan-kekuatan politik yang duduk di DPRD. Sebab DPRD adalah lembaga politik yang keanggotaannya berasal dari perwakilan partai-partai politik yang berhimpun dalam berbagai fraksi politiknya masing-masing. Karena masing-masing partai politik memiliki kepentingan, visi, agenda yang berbeda-beda, maka sangat mungkin dalam proses pembahasan ini suatu Raperda memasuki wilayah kontestasi politik yang merepresentasikan kepentingan masing-masing perwakilan partai politik tersebut.

Pada tahap pembahasan ini pula nasib aspirasi masyarakat yang telah disalurkan

28 Hasil wawancara mendalam dengan M. Nur Nukuhehe, S.H. (Ketua Badan Pembentukan Peraturan Daerah DPRD Kabupaten Maluku Tengah), 15 April 2015. 
pada tahap sebelumnya terutama pada tahap penyiapan naskah Raperda dipertaruhkan. Tahapan ini mengandaikan dua kemungkinan sekaligus apakah aspirasi itu terus diperjuangkan hingga akhir pembahasan ataukah direduksi bahkan diabaikan sama sekali akibat dominasi kepentingan DPRD atau Bupati. Dengan tertutupnya akses partisipasi masyarakat pada tahap pembahasan dalam Tata Tertib DPRD, maka nasib kepentingan masyarakat yang telah

\section{e. Analisis Partisipasi Masyarakat Pada Tahap Pengundangan Peraturan Daerah}

Tempat pengundangan resmi Perda dilakukan dalam Lembaran Daerah, untuk menempatkan secara resmi berbagai Perda agar diketahui oleh masyarakat luas. Adapun produk Perda mengenai Pajak dan Retribusi berdasarkan tahun pengundangannya di Kabupaten Maluku Tengah, yakni:

Tabel 2. Jumlah Produk Perda Kabupaten Maluku Tengah Mengenai Pajak dan Retribusi

\begin{tabular}{ccccc} 
& \multirow{2}{*}{ Tahun } & \multicolumn{2}{c}{ Perihal } & \\
\cline { 3 - 4 } & Pengundangan & Pajak Daerah & Retribusi Daerah & Total \\
\hline 1. & 2007 & 6 & 9 & 15 \\
\hline 2. & 2009 & - & 9 & 9 \\
\hline 3. & 2012 & 6 & 9 & 15 \\
\hline & Total & 12 & 27 & 39 \\
\hline
\end{tabular}

Sumber: Bagian Hukum Sekretariat Daerah Kabupaten Maluku Tengah (Diolah Peneliti, 2015)

diaspirasikan pada tahap sebelumnya menjadi tidak jelas.

Adapun bentuk partisipasi masyarakat yang dapat dilakukan pada tahap ini untuk menjamin adanya tahapan pembahasan Raperda yang responsif adalah dalam bentuk (i) audiensi/ Rapat Dengar Pendapat Umum; (ii) mengajukan Raperda Alternatif; (iii) memberikan masukan melalui media cetak; (iv) memberikan masukan melalui media elektronik; (v) melakukan unjuk rasa; dan (vi) melakukan diskusi, lokakarya, dan seminar.
Partisipasi masyarakat dalam tahapan ini tidak terlihat. Hal ini disertai pula dengan terbatasnya publikasi dan sosialisasi produk Perda mengenai Pajak dan Retribusi yang telah di undangkan dalam lembaran daerah. Publikasi hanya dilakukan dalam bentuk buku yang dicetak secara terbatas untuk kalangan internal DPRD dan Pemerintah Daerah sedangkan sosialisasi sejauh ini belum pernah dilakukan. ${ }^{29}$

Padahal pada tahap inilah suatu produk Perda mempunyai makna dalam kehidupan riil masyarakat. Sebab, dengan pengundangannya

Hasil wawancara mendalam dengan Ketua Asosiasi Pengusaha Hotel Maluku Tengah, 17 April 2015, begitu pula hasil wawancara dengan M. Nur Nukuhehe, S.H. (Ketua Badan Pembentukan Peraturan Daerah DPRD Kabupaten Maluku Tengah), 15 April 2015 dan Z. Latekay, S.H. (Kepala Bagian Hukum Sekretariat Daerah Kabupaten Maluku Tengah), 21 April 2015. 
di lembaran daerah maka Perda sebagai produk hukum secara positif memiliki sifat formil untuk berlaku.

Agar tahapan pengundangan Perda dapat dilaksanakan menjadi tahapan yang responsif, maka bentuk partisipasi masyarakat yang dapat dilakukan adalah dalam bentuk: (i) unjuk rasa terhadap Perda yang baru; (ii) tuntutan uji materiil terhadap Perda; dan (iii) melakukan sosialisasi Perda.

\section{Materi Muatan Peraturan Daerah Mengenai Pajak di Maluku Tengah}

\section{a. Jenis Pajak Daerah dan Retribusi Daerah yang Dapat Diatur oleh Kabupaten Maluku Tengah}

Secara normatif, materi muatan yang terdapat dalam Perda Kabupaten Maluku Tengah mengenai Pajak dan Retribusi merupakan kesatuan tata norma dalam sistem perundangundangan Indonesia, sebagaimana yang dirumuskan dalam Pasal 14 Undang-undang Nomor 12 Tahun 2011 tentang Pembentukan Peraturan Perundang-Undangan, bahwa: "Materi muatan Peraturan Daerah Provinsi dan Peraturan Daerah Kabupaten/Kota berisi materi muatan dalam rangka penyelenggaraan otonomi daerah dan tugas pembantuan serta menampung kondisi khusus daerah dan/atau penjabaran lebih lanjut Peraturan Perundangundangan yang lebih tinggi".

Pajak Daerah dirumuskan sebagai kontribusi wajib kepada Daerah yang terutang oleh orang pribadi atau badan yang bersifat memaksa berdasarkan undang-undang, dengan tidak mendapatkan imbalan secara langsung dan digunakan untuk keperluan daerah bagi sebesarbesarnya kemakmuran rakyat. ${ }^{30}$

Pajak Daerah dibedakan atas Pajak Provinsi dan Pajak Kabupaten/Kota. Jenis Pajak Provinsi terdiri atas: (a) Pajak Kenderaan Bermotor; (b) Bea Balik Nama Kenderaan Bermotor; (c) Pajak Bahan Bakar Kenderaan Bermotor; (d) Pajak Air Permukaan; dan (e) Pajak Rokok. Sedangkan jenis Pajak Kabupaten/Kota meliputi: (a) Pajak Hotel; (b) Pajak Restoran; (c) Pajak Hiburan; (d) Pajak Reklame; (e) Pajak Penerangan Jalan; (f) Pajak Mineral Bukan Logam dan Batuan; (g) Pajak Parkir; (h) Pajak Air Tanah; (i) Pajak Sarang Burung Walet; (j) Pajak Bumi dan Bangunan Perdesaaan dan Perkotaan; serta (k) Pajak Perolehan Hak Atas Tanah dan Bangunan. Berdasarkan hal tersebut, jenis Pajak Daerah yang menjadi kewenangan pengaturan oleh Kabupaten Maluku Tengah adalah seluruh jenis Pajak yang termasuk dalam Jenis Pajak Kabupaten/Kota.

Sedangkan, Retribusi daerah merupakan pengutan Daerah sebagai pembayaran atas jasa atau pemberian izin tertentu yang khusus disediakan dan/atau diberikan oleh Pemerintah Daerah untuk kepentingan orang pribadi atau badan. ${ }^{31}$ Adapun penggolongan Retribusi Daerah dalam Undang-Undang Nomor 28 Tahun 2009 tentang Pajak Daerah dan Retribusi Daerah adalah sebagai berikut: ${ }^{32}$

$30 \quad$ Pasal 1 angka 10 Undang-Undang Nomor 28 Tahun 2009 tentang Pajak Daerah dan Retribusi Daerah.

31 Pasal 1 angka 64 Undang-Undang Nomor 28 Tahun 2009 tentang Pajak Daerah dan Retribusi Daerah.

32 Dalam Pasal 150 Undang-Undang Nomor 28 Tahun 2009 Tentang Pajak Daerah dan Retribusi Daerah ditegaskan bahwa selain yang ditetapkan dalam Pasal 110 ayat (1), Pasal 127, dan Pasal 141 dapat dipungut dengan kriteria sebagaimana yang telah ditentukan. 
Tabel 3. Penggolongan Retribusi Daerah

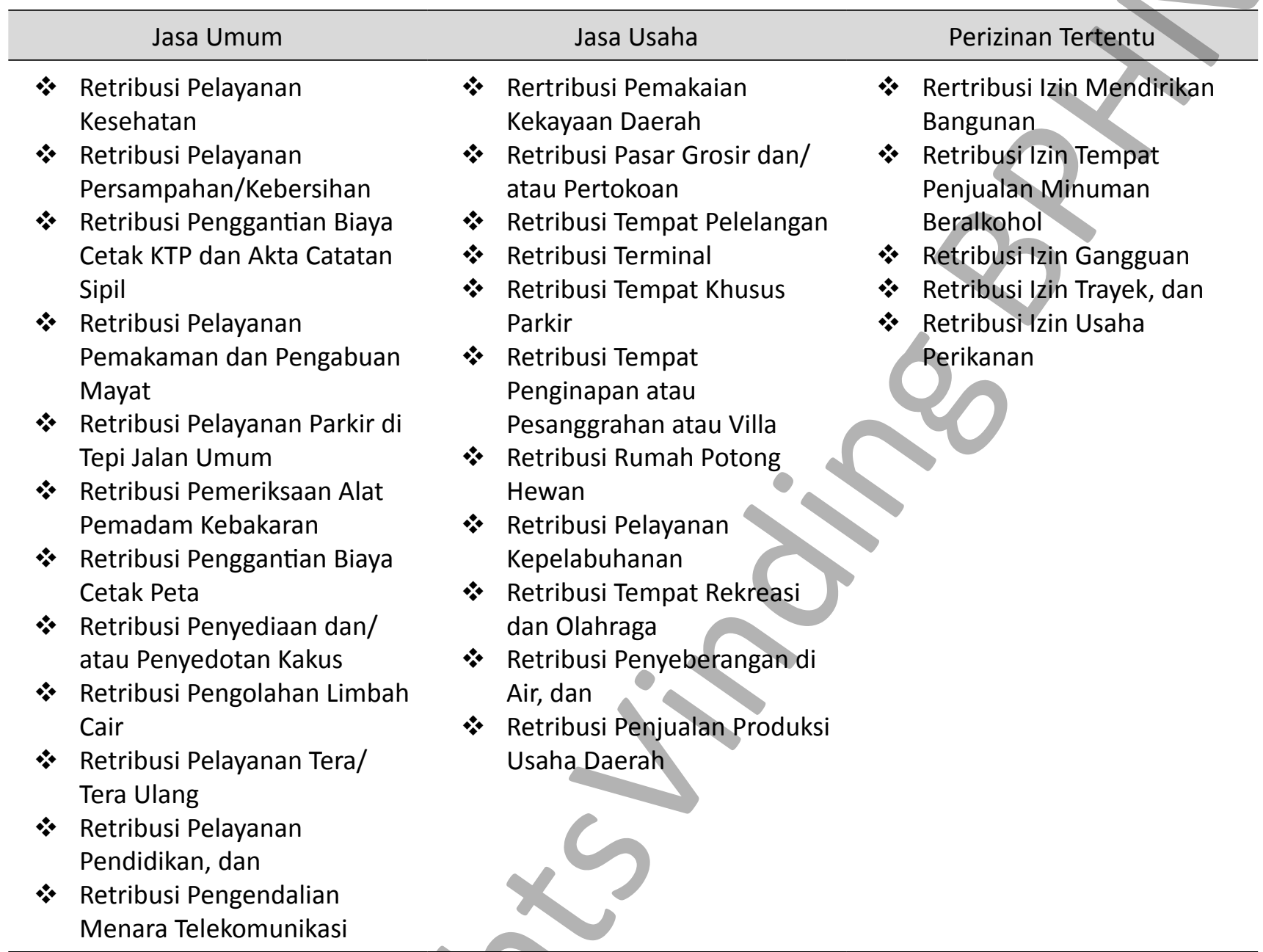

Sumber : Undang-Undang Nomor 28 Tahun 2009 Tentang Pajak daerah dan Retribusi Daerah (Diolah Peneliti, 2015)

Mengacu pada ketentuan itu, maka sumber normatif pengaturan materi muatan Peraturan Daerah Mengenai Pajak dan Retribusi adalah dalam rangka penyelenggaraan otonomi daerah sekaligus penjabaran lebih lanjut Peraturan Perundang-undangan yang lebih tinggi, yakni Undang-Undang Nomor 28 Tahun 2009 tentang Pajak Daerah dan Retribusi Daerah.

Dengan demikian, keberadaan UndangUndang Nomor 28 Tahun 2009 tentang Pajak Daerah dan Retribusi Daerah menjadi landasan kewenangan baik secara formil maupun materiil bagi Kabupaten Maluku Tengah sebagai daerah otonom dalam menerbitkan Peraturan Daerah mengenai Pajak dan Retribusi.

\section{b. Analisis Akomodasi Aspirasi Masyarakat dalam Materi Muatan Peraturan Daerah Kabupaten Maluku Tengah Mengenai Pajak dan Retribusi}

Selain proses pembentukan yang partisipatif, indikator legislasi responsif berkaitan dengan materi muatannya yang aspiratif yakni materimateri yang diatur dalam suatu Peraturan Daerah secara umum sesuai dengan aspirasi atau kehendak masyarakat yang dilayaninya. 
Dalam konteks ini, perspektif legislasi responsif berkaitan dengan jenis Pajak Daerah dan Retribusi Daerah yang diatribusikan kewenangan pengaturannya melalui Peraturan Daerah mengakomodasi adanya aspirasi masyarakat dalam materi muatannya.

Berdasarkan temuan Peneliti, pada tahap perencanaan Peraturan Daerah mengenai Pajak dan Retribusi tidak menampakkan adanya aspirasi masyarakat. Hal ini disebabkan karena pada tahap penyusunan program legislasi daerah Kabupaten Maluku Tengah sama sekali tidak melibatkan sedikitpun partisipasi masyarakat. Padahal idealnya, sejak pada tahap perencanaan ini, program legislasi daerah sudah dapat mencerminkan aspirasi masyarakat tentang rencana legislasi yang diprioritaskan termasuk rencana Peraturan Daerah mengenai Pajak dan Retribusi.

Adapun pada tahap penyusunan Rancangan Peraturan Daerah mengenai Pajak dan Retribusi khususnya pada tahap penelitian dan pengkajian menunjukan kenyataan yang sama, yakni tidak ada aspirasi masyarakat yang berkaitan dengan landasan akademis dari rancangan Peraturan Daerah dimaksud. Hal ini berkaitan dengan tidak adanya partisipasi masyarakat terutama dari kalangan akademisi ataupun para pakar yang kompeten dalam bidang yang akan diatur oleh Peraturan Daerah mengenai Pajak dan Retribusi.

Sedangkan pada tahap penyusunan naskah Rancangan Peraturan Daerah mengenai Pajak dan Retribusi, pada umumnya sudah terlihat adanya partisipasi masyarakat dalam bentuk forum dengar pendapat (public hearing) untuk memberi masukan tentang rancangan Peraturan
Daerah dimaksud. Dalamforum dengar pendapat tersebut isu yang mendapatkan perhatian khusus adalah mengenai besar nilai tarif Pajak.

Namun, pada tahap selanjutnya yakni pembahasan, pengesahan, penetapan, dan pengundangan, aspirasi masyarakat yang mengedepan di forum dengar pendapat mengenai besar nilai tarif yang diharapkan untuk disesuaikan dengan kemampuan ekonomi pengunjung dan kondisi ekonomi daerah saat ini dalam kenyataannya tidak diakomodir. Besar nilai tarif Pajak Hotel dan Pajak Restoran yang diharapkan oleh masyarakat di forum itu adalah sekitar $5 \%$, tetapi yang disepakati dan ditetapkan oleh DPRD dan Pemerintah Daerah tetap mengacu pada nilai maksimal yang ditentukan dalam Undang-Undang Nomor 28 Tahun 2009 tentang Pajak Daerah dan Retribusi Daerah, yakni sebesar $10 \% .^{33}$

Adapun Produk Peraturan daerah berdasarkan Jenis Pajak dan Retribusi yang telah diundangkan dalam Lembaran daerah Kabupaten Maluku Tengah, sebagai berikut:

33 Hasil wawancara mendalam dengan Ketua Asosiasi Pengusaha Hotel Maluku Tengah, 17 April 2015. 
Tabel 4. Produk Peraturan Daerah Kabupaten Maluku Tengah Mengenai Pajak dan Retribusi Tahun 2012

\begin{tabular}{|c|c|c|c|c|}
\hline No & Nama Peraturan Daerah & $\begin{array}{l}\text { Jumlah } \\
\text { Pasal }\end{array}$ & $\begin{array}{c}\text { Besar Tarif Pajak/ } \\
\text { Retribusi }\end{array}$ & Lembaran Daerah \\
\hline 1. & $\begin{array}{l}\text { Peraturan Daerah Kabupaten } \\
\text { Maluku Tengah Nomor } 15 \\
\text { Tahun } 2012 \text { Tentang Pajak Air } \\
\text { Tanah }\end{array}$ & 38 Pasal & $20 \%$ & $\begin{array}{l}\text { Lembaran Daerah Kabupaten } \\
\text { Maluku Tengah Tahun } 2012 \\
\text { Nomor } 121\end{array}$ \\
\hline 2. & $\begin{array}{l}\text { Peraturan Daerah Kabupaten } \\
\text { Maluku Tengah Nomor } 16 \\
\text { Tahun 2012 Tentang Pajak } \\
\text { Hiburan }\end{array}$ & 41 Pasal & $\begin{array}{l}\text { Variatif berdasarkan } \\
\text { jenis hiburan }\end{array}$ & $\begin{array}{l}\text { Lembaran Daerah Kabupaten } \\
\text { Maluku Tengah Tahun } 2012 \\
\text { Nomor } 122\end{array}$ \\
\hline 3. & $\begin{array}{l}\text { Peraturan Daerah Kabupaten } \\
\text { Maluku Tengah Nomor } 17 \\
\text { Tahun 2012 Tentang Pajak } \\
\text { Hotel }\end{array}$ & 41 Pasal & $10 \%$ & $\begin{array}{l}\text { Lembaran Daerah Kabupaten } \\
\text { Maluku Tengah Tahun } 2012 \\
\text { Nomor } 123\end{array}$ \\
\hline 4. & $\begin{array}{l}\text { Peraturan Daerah Kabupaten } \\
\text { Maluku Tengah Nomor } 18 \\
\text { Tahun } 2012 \text { Tentang Pajak } \\
\text { Mineral Bukan Logam dan } \\
\text { Batuan }\end{array}$ & & & $\begin{array}{l}\text { Lembaran Daerah Kabupaten } \\
\text { Maluku Tengah Tahun } 2012 \\
\text { Nomor } 124\end{array}$ \\
\hline 5. & $\begin{array}{l}\text { Peraturan Daerah Kabupaten } \\
\text { Maluku Tengah Nomor } 19 \\
\text { Tahun 2009 Tentang Pajak } \\
\text { Restoran }\end{array}$ & & & $\begin{array}{l}\text { Lembaran Daerah Kabupaten } \\
\text { Maluku Tengah Tahun } 2012 \\
\text { Nomor } 125\end{array}$ \\
\hline 6. & $\begin{array}{l}\text { Peraturan Daerah Kabupaten } \\
\text { Maluku Tengah Nomor } 20 \\
\text { Tahun 2012 Tentang Bea } \\
\text { Perolehan Hak Atas Tanah dan } \\
\text { Bangunan }\end{array}$ & & $5 \%$ & $\begin{array}{l}\text { Lembaran Daerah Kabupaten } \\
\text { Maluku Tengah Tahun } 2012 \\
\text { Nomor } 126\end{array}$ \\
\hline 7. & $\begin{array}{l}\text { Peraturan Daerah Kabupaten } \\
\text { Maluku Tengah Nomor 21 } \\
\text { Tahun } 2012 \text { Tentang Retribusi } \\
\text { Izin Usaha Perikanan }\end{array}$ & 20 Pasal & $\begin{array}{c}\text { Variatif berdasarkan } \\
\text { jenis usaha perikanan } \\
\text { tangkap dan perikanan } \\
\text { budidaya. }\end{array}$ & $\begin{array}{l}\text { Lembaran Daerah Kabupaten } \\
\text { Maluku Tengah Tahun } 2012 \\
\text { Nomor } 127\end{array}$ \\
\hline 8. & $\begin{array}{l}\text { Peraturan Daerah Kabupaten } \\
\text { Maluku Tengah Nomor } \\
22 \text { Tahun } 2012 \text { Tentang } \\
\text { Retribusi Tempat Penginapan/ } \\
\text { Pesanggrahan/Vila }\end{array}$ & 24 Pasal & $\begin{array}{l}\text { Variatif berdasarkan } \\
\text { jenis fasilitas, } \\
\text { lokasi, jangka waktu } \\
\text { pemakaian. }\end{array}$ & $\begin{array}{l}\text { Lembaran Daerah Kabupaten } \\
\text { Maluku Tengah Tahun } 2012 \\
\text { Nomor } 128\end{array}$ \\
\hline 9. & $\begin{array}{l}\text { Peraturan Daerah Kabupaten } \\
\text { Maluku Tengah Nomor } 23 \\
\text { Tahun } 2012 \text { Tentang Retribusi } \\
\text { Tempat Rekreasi dan Olahraga }\end{array}$ & 22 Pasal & $\begin{array}{l}\text { Variatif berdasarkan } \\
\text { frekuensi, jenis, } \\
\text { dan jangka waktu } \\
\text { layanan tempat } \\
\text { rekreasi, pariwisata } \\
\text { dan olahraga yang } \\
\text { disediakan, dimiliki, } \\
\text { dan atau dikelola oleh } \\
\text { Pemerintah Daerah. }\end{array}$ & $\begin{array}{l}\text { Lembaran Daerah Kabupaten } \\
\text { Maluku Tengah Tahun } 2012 \\
\text { Nomor } 129\end{array}$ \\
\hline
\end{tabular}




\begin{tabular}{|c|c|c|c|c|}
\hline No & Nama Peraturan Daerah & $\begin{array}{l}\text { Jumlah } \\
\text { Pasal }\end{array}$ & $\begin{array}{c}\text { Besar Tarif Pajak/ } \\
\text { Retribusi }\end{array}$ & Lembaran Daerah \\
\hline 10. & $\begin{array}{l}\text { Peraturan Daerah Kabupaten } \\
\text { Maluku Tengah Nomor 24 } \\
\text { Tahun } 2012 \text { Tentang Retribusi } \\
\text { Pelayanan Kepelabuhanan }\end{array}$ & 25 Pasal & $\begin{array}{c}\text { Variatif berdasarkan, } \\
\text { jangka waktu } \\
\text { pemakaian, jenis } \\
\text { pelayanan dan volume }\end{array}$ & $\begin{array}{l}\text { Lembaran Daerah Kabupaten } \\
\text { Maluku Tengah Tahun } 2012 \\
\text { Nomor } 130\end{array}$ \\
\hline 11 & $\begin{array}{l}\text { Peraturan Daerah Kabupaten } \\
\text { Maluku Tengah Nomor 25 } \\
\text { Tahun } 2012 \text { Tentang Retribusi } \\
\text { Izin Mendirikan Bangunan }\end{array}$ & 34 Pasal & $\begin{array}{l}\text { Variatif berdasarkan } \\
\text { tingkat penggunaan } \\
\text { jasa, jenis bangunan, } \\
\text { dan harga dasar } \\
\text { bangunan atau rencana } \\
\text { anggaran biaya (RAB) }\end{array}$ & $\begin{array}{l}\text { Lembaran Daerah Kabupaten } \\
\text { Maluku Tengah Tahun } 2012 \\
\text { Nomor } 131\end{array}$ \\
\hline 12 & $\begin{array}{l}\text { Peraturan Daerah Kabupaten } \\
\text { Maluku Tengah Nomor } 26 \\
\text { Tahun } 2012 \text { Tentang Retribusi } \\
\text { Izin Tempat Penjualan } \\
\text { Minuman Beralkohol }\end{array}$ & & $\begin{array}{l}\text { Variatif berdasarkan } \\
\text { jenis minuman } \\
\text { beralkohol yang dijual }\end{array}$ & $\begin{array}{l}\text { Lembaran Daerah Kabupaten } \\
\text { Maluku Tengah Tahun } 2012 \\
\text { Nomor } 132\end{array}$ \\
\hline 13 & $\begin{array}{l}\text { Peraturan Daerah Kabupaten } \\
\text { Maluku Tengah Nomor } 27 \\
\text { Tahun } 2012 \text { Tentang Retribusi } \\
\text { Pasar Grosir dan / Pertokoan }\end{array}$ & 21 Pasal & $\begin{array}{l}\text { Variatif berdasarkan } \\
\text { jenis, luas ukuran } \\
\text { dan jangka waktu } \\
\text { pemakaian pasar grosir } \\
\text { dan /pertokoan }\end{array}$ & $\begin{array}{l}\text { Lembaran Daerah Kabupaten } \\
\text { Maluku Tengah Tahun } 2012 \\
\text { Nomor } 133\end{array}$ \\
\hline 14 & $\begin{array}{l}\text { Peraturan Daerah Kabupaten } \\
\text { Maluku Tengah Nomor 28 } \\
\text { Tahun } 2012 \text { Tentang Retribusi } \\
\text { Pelayanan Pasar }\end{array}$ & 22 Pasal & $\begin{array}{l}\text { Variatif berdasarkan } \\
\text { jenis, luas ukuran, } \\
\text { dan jangka waktu } \\
\text { pemakaian dari masing- } \\
\text { masing fasilitas serta } \\
\text { kelas pasar yang } \\
\text { digunakan }\end{array}$ & $\begin{array}{l}\text { Lembaran Daerah Kabupaten } \\
\text { Maluku Tengah Tahun } 2012 \\
\text { Nomor } 134\end{array}$ \\
\hline 15 & $\begin{array}{l}\text { Peraturan Daerah Kabupaten } \\
\text { Maluku Tengah Nomor } 29 \\
\text { Tahun } 2012 \text { Tentang Retribusi } \\
\text { Penggantian Biaya Cetak Peta }\end{array}$ & 3 Pasal & $\begin{array}{l}\text { Variatif berdasarkan } \\
\text { setiap sentimeter } \\
\text { persegi peta dan jenis } \\
\text { bahan kertas peta yang } \\
\text { disediakan }\end{array}$ & $\begin{array}{l}\text { Lembaran Daerah Kabupaten } \\
\text { Maluku Tengah Tahun } 2012 \\
\text { Nomor } 135\end{array}$ \\
\hline
\end{tabular}

Sumber: Bagian Hukum Setda Kabupaten Maluku Tengah (Diolah Penulis, 2015)

Dengan demikian, jika dicermati substansi yang dikehendaki oleh masyarakat dalam forum dengar pendapat pada tahap perancangan Peraturan Daerah mengenai Pajak dan Retribusi terlihat bahwa forum dengar pendapat atau public hearing tersebut hanya bersifat formalitas belaka sebab pada tahapan selanjutnya yakni pembahasan, pengesahan, penetapan, dan pengundangan, aspirasi masyarakat tentang besar nilai Tarif tidak terealisir sebagaimana yang dikehendaki.
Sekalipun secara umum substansi materi muatan Peraturan Daerah mengenai Pajak dan Retribusi yang telah diundangkan dalam Lembaran Daerah di atas tidak aspiratif, namun dalam tahap pengundangan tidak terdapat respon atau reaksi masyarakat untuk mengkritisi ataupun menolak Peraturan Daerah tersebut baik dalam bentuk unjuk rasa ataupun mengajukan tuntutan uji materiil terhadap Peraturan Daerah. 


\section{Penutup}

Berdasarkan hasil penelitian dan analisisnya dapat dirumuskan kesimpulan bahwa: Pertama, Proses pembentukan Peraturan Daerah mengenai Pajak dan Retribusi di Kabupaten Maluku Tengah belum berperspektif legislasi responsif, sebab secara umum, dalam keseluruhan tahapan pembentukan Peraturan Daerah mengenai Pajak dan Retribusi tersebut belum terlihat adanya partisipasi masyarakat yang memadai. Pada tahap penyusunan rancangan Peraturan Daerah terdapat partisipasi masyarakat dalam bentuk forum dengar pendapat (public hearing), namun dari aspek kuantitatif masih minim dan dari aspek pelaku partisipasi masih bersifat terbatas. Sedangkan pada tahap selanjutnya yakni tahap pembahasan dan pengundangan, sama sekali tidak melibatkan partisipasi masyarakat.

Kedua, adapun materi muatan yang terkandung dalam Peraturan Daerah mengenai Pajak dan Retribusi di Kabupaten Maluku Tengah belum berperspektif legislasi responsif, sebab aspirasi masyarakat yang mengemuka di forum dengar pendapat (public hearing) pada tahap penyusunan naskah rancangan Peraturan Daerah mengenai Pajak dan Retribusi tidak diakomodir dalam tahap pembahasan maupun pengundangannya di Lembaran Daerah. Sebelumnya, pada tahap perencanaan Peraturan Daerah dalam wujud program legislasi daerah juga tidak mencerminkan adanya aspirasi masyarakat dalam menentukan prioritas legislasi mengenai Pajak dan Retribusi yang akan di bentuk.

Berdasarkan hal tersebut maka untuk dapat mewujudkan suatu Peraturan Daerah mengenai Pajak dan Retribusi yang berperspektif legislasi responsif yang pada gilirannya dapat berkesesuaian dengan tujuan otonomi daerah, maka hendaknya dalam proses pembentukan Peraturan Daerah mengenai Pajak dan Retribusi di Kabupaten Maluku Tengah harus melibatkan partisipasi amsyarakat mulai dari perencanaan, pembahasan, dan pengundangannya di Lembaran Daerah. Begitu juga materi muatan Peraturan Daerah haruslah seluas mungkin dapat mengakomodir aspirasi atau kehendak masyarakat.

Untuk dapat mewujudkan hal ini, maka prioritaspembenahan perludimulaidarimerevisi Peraturan DPRD Kabupaten Maluku Tengah Nomor 01 Tahun 2014 tentang Peraturan Tata Tertib DPRD sehingga memungkinkan adanya akses partisipasi masyarakat pada keseluruhan tahapan proses pembentukan Peraturan Daerah serta transformasi dan pemberdayaan kultur politik masyarakat yang masih bersifat top down atau konservatif menjadi kultur politik yang button up atau responsif.

\section{DAFTAR PUSTAKA}

\section{Buku}

Fadjar, Mukhtie, Teori-Teori Hukum Kontemporer (Malang: Setara Press, 2013)

Hamidi, Jazim et.al, Panduan Praktis Pembentukan Peraturan Daerah Partisipatif (Jakarta: Prestasi Pustaka Publisher, 2008)

Mahfud, Moh M.D, Politik Hukum Di Indonesia (Jakarta: PT RajaGrafindo Persada, 2009)

Nonet, Philippe dan Philip Selznick, Hukum Responsif, Penerjemah (Raisul Muttaqien), Cetakan Kedua (Bandung: Nusa Media, 2008)

Ruslan, Achmad, Teori dan Panduan Pembentukan Peraturan Perundang-Undangan Di Indonesia (Yogyakarta: Mahakarya Rangkang Offset, 2011)

Sutedi, Adian, Hukum Pajak dan Retribusi Daerah (Bogor: Ghalia Indonesia, 2008)

\section{Makalah/Artikel/Prosiding/Hasil Penelitian}

Arianto, Henry, "Hukum Responsif dan Penegakkan Hukum Di Indonesia", Jurnal Lex Jurnalica, Vol. 7 No. 2, April (2010) 
Arrsa, Ria Casmi, "Restorasi Politik Legislasi Pembentukan Peraturan Daerah Berbasis Riset", Jurnal Rechtsvinding, Vol. 2 No. 3, Desember (2013)

Bagijo, Himawan Estu, “Pajak Dan Retribusi Daerah Sebagai Sumber Pendapatan Daerah (Studi Kasus Di Kabupaten/Kota Dan Pemerintah Propinsi Di Jawa Timur)", Jurnal Perspektif, Vol. XVI No. 1 (2011)

Basyir, Abdul, "Pentingnya Naskah Akademik Dalam Pembentukan Peraturan Perundangundangan Untuk Mewujudkan Hukum Aspiratif Dan Responsif", Jurnal lus, Vol. II No.5, Agustus (2014)

Hattu, Hendrik, "Tahapan Undang-Undang Responsif", Jurnal Mimbar Hukum, Vol. 23 No. 2, Tahun (2011)

Hattu, Hendrik, 2010. Model Undang-Undang Berkarakter Responsif (Studi Atas UndangUndang Nomor 32 Tahun 2004 tentang Pemerintahan Daerah), Ringkasan Disertasi (Makassar: Program Pasca Sarjana Universitas Hasanuddin, 2010)

Hikmawati, "Partisipasi Masyarakat Dalam Perumusan Kebijakan Publik", Jurnal Politik Profetik, Vol. 1 No. 1 (2013)

Isrok, "Korelasi Antara Peraturan Daerah (Perda) bermasalah dengan Tingkat Investasi Ke Daerah", Jurnal Hukum, Vol. 16 No. 4 (2009)

Jusup,H.M, “Perda Pajak Dan Retribusi Daerah Di Era Otonomi Daerah, Jurnal Ekonomi, Vol. 1 No. 1 September-Desember (2012)

Rodiyah, "Aspek Demokrasi Pembentukan Peraturan Daerah Dalam Perspektif Socio-Legal", Jurnal MMH, Jilid 41 No. 1 (2012)
Rumesten, Iza R.S, "Model Ideal Partisipasi Masyarakat Dalam Pembentukan Peraturan Daerah", Jurnal Dinamika Hukum,Vol. 12 No.1, Januari (2012)

Rumesten, Iza, R.S, "Strategi Hukum dan Penerapan Partisipasi Masyarakat dalam Penyelesaian Sengketa Batas Daerah di Sumatera Selatan", Jurnal Hukum lus Quia lustum, Vol. 20 No. 4 (2013)

Saragih, Tomy M, “Konsep Partisipasi Masyarakat Dalam Pembentukan Peraturan Daerah Rencana Detail Tata Ruang dan Kawasan", Jurnal Sasi, Vol. 17, No. 3 (2011)

Syaifuddin, Muhammad, et.al, "Demokratisasi Peraturan Daerah: Pengembangan Model Ideal Pembentukan Peraturan Daerah Demokratis di Bidang Ekonomi di Kabupaten/Kota di Provinsi Sumatera Selatan", Jurnal MMH, Jilid 39 No. 2 (2010)

\section{Peraturan}

Undang-Undang Nomor 12 Tahun 2011 tentang Pembentukan Peraturan Perundang-Undangan.

Peraturan Dewan Perwakilan Rakyat Daerah Kabupaten Maluku Tengah Nomor 01 Tahun 2009 Tentang Tata Tertib Dewan Perwakilan Rakyat Daerah Kabupaten Maluku Tengah.

Peraturan Dewan Perwakilan Rakyat Daerah Kabupaten Maluku Tengah Nomor 01 Tahun 2014 Tentang Tata Tertib Dewan Perwakilan Daerah Kabupaten Maluku Tengah.

Keputusan Menteri Dalam Negeri Tentang Pembatalan Peraturan Daerah dan Keputusan Kepala Daerah Tahun 2005-2009 